\title{
L'atténuation de la houle en fonction de la profondeur
}

\author{
PAR L. DRAPER
}

D) NATONAL INSTITLTE OF OCEANOGRAPHY (WOMMLEY, ROYALME-UNi)

\section{Attenuation of sea waves with depth}

\author{
IY L. DRAPER \\ NATIONAL, INSTITLTE OF OCEANOGHAPHY, L.K.
}

\begin{abstract}
L'article relate des expériences comparant les ondes de surface avec les variations de pression qu'elles engendrent sur le fond de la mer en un point assez proche d'une plage. L'atténualion des ondes est comparée à celle qu'on calcule au moyen de la théorie hydrodynamique rlassique. On propose une équation empirique concordant avec les résultats obtenus.
\end{abstract}

The paper describes an experimental comparison of surface waves with the pressure changes produced by them on the sea bed at a point fairly near to a beach. The attenuation of the waves is compared with that calculated by classical hydrodynamic theory. An empirical equation is evolved which agrees with these results.
Des tentalives onl été failes dans le passé pour préciser la validité des équations classiques de l'hydrodynamique qui régissent l'amortissement des ondes progressives à la surface d'un liquide en fonction de la profondeur [1] : des mesures ont été effectuées à cet effet dans des bassins expérimentaux aussi bien qu'en mer. Le plus souvent, ces mesures étant entachées de fortes incertitudes soit dans la précision des enregistrements, soit dans les procédés d'analyse.

La difficulté la plus grande provenait d'ordinaire de l'enregistrement des amplitudes en surface, la mesure précise des variations de pression ctant par contre une technique bien au point. Il n'y a pas grand intérêt à comparer directement entre elles les amplitudes, au fond et en surface, d'ondes individuelles sur une mer agitéc, car on ne connaît pas les longueurs d'ondes de leurs composantes; il est donc impossible de prévoir les hauteurs relatives avant de connaître le spectre fourni par les enregistrements. Or, gràce au fait que l'Institut National d'Océanographie de Grande-Bretagne dispose de deux types d'appareils appropriés d'enregistreurs de houle (l'un pour les mesures en surface, l'autre pour la mesure des pressions), grâce d'autre parl à une méthode précise d'enregistrement photographique et à un analyseur Fourier d'harmo-
Attempts have been made in the past to determine the validity of the classical Hydrodynamic equations governing the attenuation with depth of progressive waves on the surface of a liquid [1]. Measurements have been made both in experimental tanks and in the sea. The majority have suffered from some major uncertainty, either in the accuracy of recording or in the methods of analysis.

Usually the greatest difficulty was experienced in recording the surface wave amplitudes, accurate measurement of pressure changes being a well developed technique. Direct comparison of the surface and bottom amplitudes of individual waves in a confused sea is of little value as the component wavelengths making up each wave are unknown; it is therefore impossible to predict the relative heights without first obtaining the spectrum of the records. The facilities offered by the existence, at the National Institute of Oceanography, of two reliable types of wave recorder (one surface and one pressure), an accurate method of photographic recording and a Fourier Analyser suggested that a useful contribution could be made to the subject by making experiments with these types of equipment. 
niques nous pouvions espérer contribuer utilement à la question.

Nous nous proposions de choisir, pour l'enregistrement, une jetée où le marnage serait aussi grand que possible, permettant de noter les variations de pression au fond pour toute une gamme de profondeurs. La jetée d'Eastbourne, sur la Manche, nous a semblé convenir tout particulierement, car elle consistait en pieux foncés dans un fond suffisamment lisse. A l'aide d'un appareil capacitif à fil [2], nous enregistrions la houle à son passage en un point déterminé de la surface de la mer. Directement sous ce point, un appareil enregistreur piézo-électrique notait les variations de pression provoquées par la houle en surface. Les valeurs données par les deux appareils étaient enregistrées simultanément sur une même bande de papier sensible
It was decided to record waves from a pier at a place with as large a tidal range as possible so that sea-bed pressure changes could be recorded in various depths of water. The pier at Eastbourne, on the English Channel, seemed to be the most suitable, being built of slender piles on fairly smooth ground. Waves were recorded by a capacitancewire wave recorder $[2]$ as they passed a point on the surface of the sea. Directly underneath this point, on the sea bed, a piezo-electric pressure unit recorded the pressure fluctuations due to the surface waves. The outputs of the two instruments were recorded simultaneously on the same length of photographic paper (fig. 1) in a form suitable for use in the N.I.O. Fourier Analyser, which produces the frequency spectrum of the record. From the measured surface spectrum the theoretical pressure
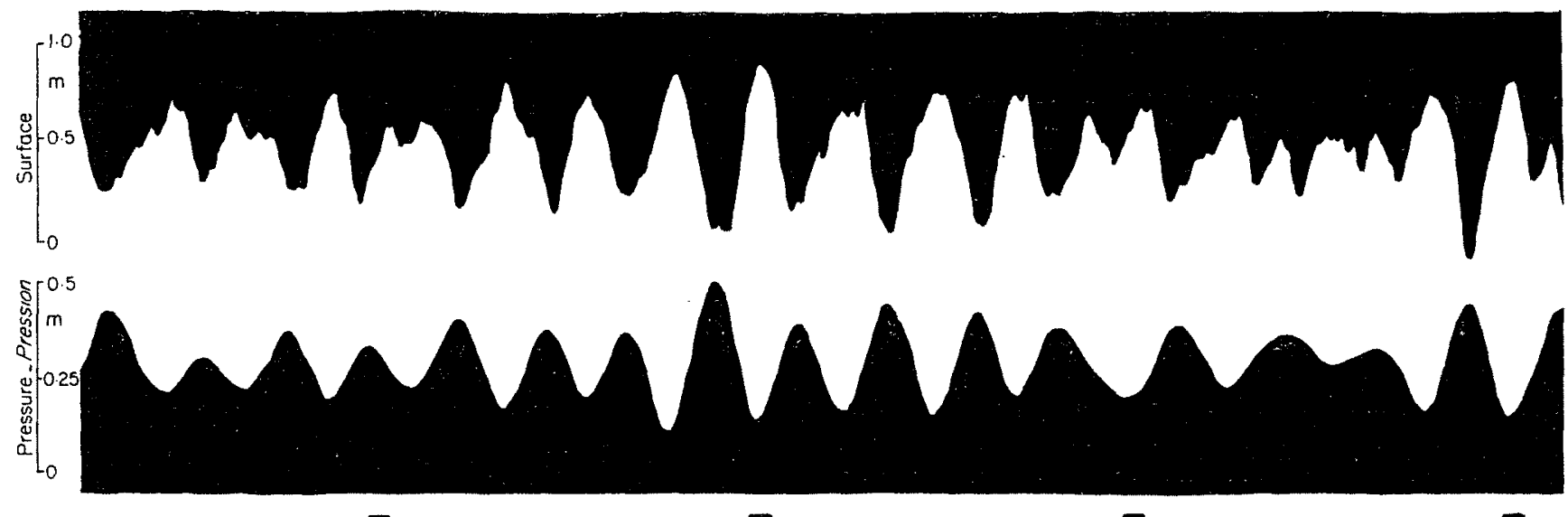

Fra. 1. - Exemple caractéristique d'enregistrement de houle et de pression sur le fond. Le tracé du haut est l'enregistrement de surface (inversé), celui du bas est l'enregistrement de pression. (I'échelle de l'enregistrement des pressions est 1,94 fois celle de l'enregistrement de surface.) Les repères de temps sont à intervalles de 20 secondes. La profondcur d'ealu est de $6,5 \mathrm{~m}$.

A typical surface and pressure wabe record. The top trare is the surface record. (The scale of the pressure resord is 1.94 times that of the surface record.) The timing pips are at 20-sec interbuls. The witer depth is 6.5 melres.

(fig. 1) sous une forme permettant leur utilisalion dans l'analyseur harmonique de l'Institut précilé, fournissant le spectre des fréquences de la bande enregistrée. D’après le spectre mesurí en surface, on calculait le spectre des pressions théoriques que l'on comparait ensuite arec le spectre des pressions effectivement mesurées.

\section{Considérations théoriques}

Selon la théorie classique, dans le cas d'un train d'ondes sinusoïdales de faible amplitude, spectrum was calculated, and this was then compar. ed with the measured pressure spectrum.

\section{Theoretical considerations}

According to the classical theory, for a smallamplitude sinusoidal wave train, the attenuation of the pressure with depth depends upon the wavelength in the following manner: 
l'attémuation de la pression en fonction de la profondeur dépend de la longueur d'onde, selon la relation :

$$
\mathrm{P}=\mathrm{A} \operatorname{sech} \frac{2 \pi d}{\lambda}
$$

ou :

$$
\mathrm{A}=\mathrm{P} \cosh 2 \pi d / \lambda .
$$

P étant la pression sur le fond de la mer mesurée en hauteur équivalente d'eau de mer;

A l'amplitude de la surface;

$d$ la profondeur;

$\lambda$ la longueur d'onde.

Les méthodes d'enregistrement ne fournissent pas directement la longueur d'onde; par contre, on en déduit facilement la période. Orr, entre la longueur d'onde el la période existe une relation unique correspondant à la formule classique suivante :

$$
\mathrm{T}=\left(\frac{g}{2 \pi \lambda} \operatorname{tgh} \frac{2 \pi d}{\lambda}\right)^{-1 / 2}
$$

oủ 'T est la période. Sibul [3], ayant observé en bassin expérimental la relation de $\mathrm{T}$ à $\lambda$ pour une gamme semblable de valeurs du rapport " longueur d'onde/profondeur », a constaté que l'équation était à peu près correcte. On admet généralement que le mouvement peut être représenté par la superposition d'un certain nombre d'ondes sinusoïdales, à condition que les carrés des vitesses des particules d'eau soient négligeables. Nous avons supposé, dans la présente analyse, que l'amplitude en surface pouvait être représentée par la somme d'un nombre infini d'ondes sinusoïdales de ce genre.

Chaque enregistrement durait environ six minutes, trop peu pour fournir le spectre vrai de l'état de la mer; mais comme les deux enregistrements se rapportent à une même onde, on peut dire qu'ils subissent les mêmes fluctuations statistiques par rapport au spectre vrai et qu'ils sont donc directement comparables.

$$
\mathrm{P}=\mathrm{A} \operatorname{sech} \frac{2 \pi d}{\lambda}
$$

or:

$$
\mathrm{A}=\mathrm{P} \cosh \frac{2 \pi d}{\lambda}
$$

where:

$\mathrm{P}=$ pressure on sea bed measured in equivalent head of sea water;

$\mathrm{A}=$ surface amplitude;

$d=$ depth of water;

$\lambda=$ wavelenth

The methods of recording do not give the wavelength directly, but the period is easily obtained. There is a unique relationship between wavelength and period yiven by the following classical expression :

$$
\mathrm{T}=\left(\frac{g}{2 \pi \lambda} \tanh \frac{2 \pi d}{\lambda}\right)^{-1 / 2}
$$

where ' $\mathrm{T}$ is the period. Sibul [3] has made tank investigations of the $T: \lambda$ relationship over a similar range of wavelength-to-depth ratios and found the equation to be substantially correct. It is assumed that any number of sinusoidal waves can be superposed to give a possible motion if the squares of the water particle velocities are negligible. In this analysis it was assumed that the sea surface amplitude could be represented as the sum of an infinite number of such sinusoidal waves.

Each wave record was of about six minutes duration. This is too short a time to obtain a truc spectrum of the sea, but since both records are of the same waves the statistical variations from the true spectrum are common to both; the records are therefore directly comparable.
Fra. 2. -- Spectres caractéristiques des enregistrements en surface et au fond (ne correspondant pas à l'enregistrement présenté fig. 1). La profondeur d'eau est de $6 \mathrm{~m}$. Les périodes explorées se rangent entre 3 et 10 secondes.

Typical spectra of the surfáce and pressure records (not of the record shown in fig. 1). The water depth is 6 metres. The periods investigated range from 3 to $10 \mathrm{sec}$.

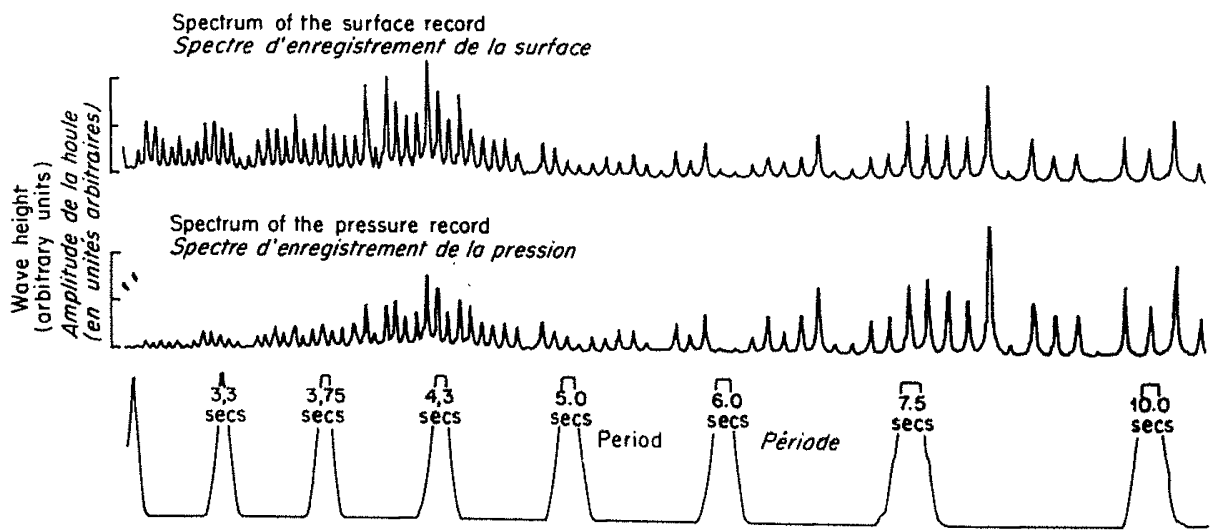




\section{Analyse des enregistrements}

Le résultat d'analyse se présente (fig. 2) comme une série de crêtes chacune correspondant à un harmonique de la longueur de la bande [4]. Chaque cas analysé a été décomposé environ en sept sections de période courte et, pour chacune d'elles, on a calculé la racine carrée de la somme des carrés des amplitudes des harmoniques. D'après cette valeur de l'amplitude, donnée par la racine carrée de la moyenne des carrés dans chacune des sections du spectre de la surface, nous avons évalué la racine carrée de la moyenne du spectre théorique des pressions au fond et les avons comparées aux amplitudes mesurées. Douze paires d'enregistrements ont été analysées ainsi et ont fourni environ quatre-vingts comparaisons entre amplitudes de surface et de fond.

Nous avons porté les rapports :

\section{$\mathrm{P}$ théorique/P réelle}

entre les variations de pression à la surface et au fond, d'abord en fonction de la période de la partie du spectre considérée, puis en fonction du coefficient d'amortissement théorique. Dans ce dernier diagramme, qui semblait donner la

\section{Analysis of the records}

A Fourier analysis (fig. 2) consists of a series of peaks, each corresponding to a harmonic of the length of the record [4]. Each analysis was divided into about seven small-period ranges. The square root of the sum of the squares of the amplitudes of the harmonics in each range was computed. From these values of the r.m.s. amplitude in each range of the surface spectrum, the r.m.s. amplitudes in the corresponding period ranges of the theoretical bottom pressurc spectrum were calculated and compared with the measured amplitudes. Twelve pairs of records were analysed, yielding about eighty comparisons of surface and pressure amplitudes. The ratios of calculated to actual pressure change on the sea bed, $P_{\text {th }} / P_{a c t}$, were plotted, first against the period of the part of the spectrum considered and then against the theoretical attenuation factor. With the latter method of presentation, which appeared to give the least scatter, the straight line derived by the method of least squares passes through $\mathrm{P}_{\mathrm{th}} / \mathrm{P}_{\mathrm{act}}=0.99$. On fig. 3 this line is

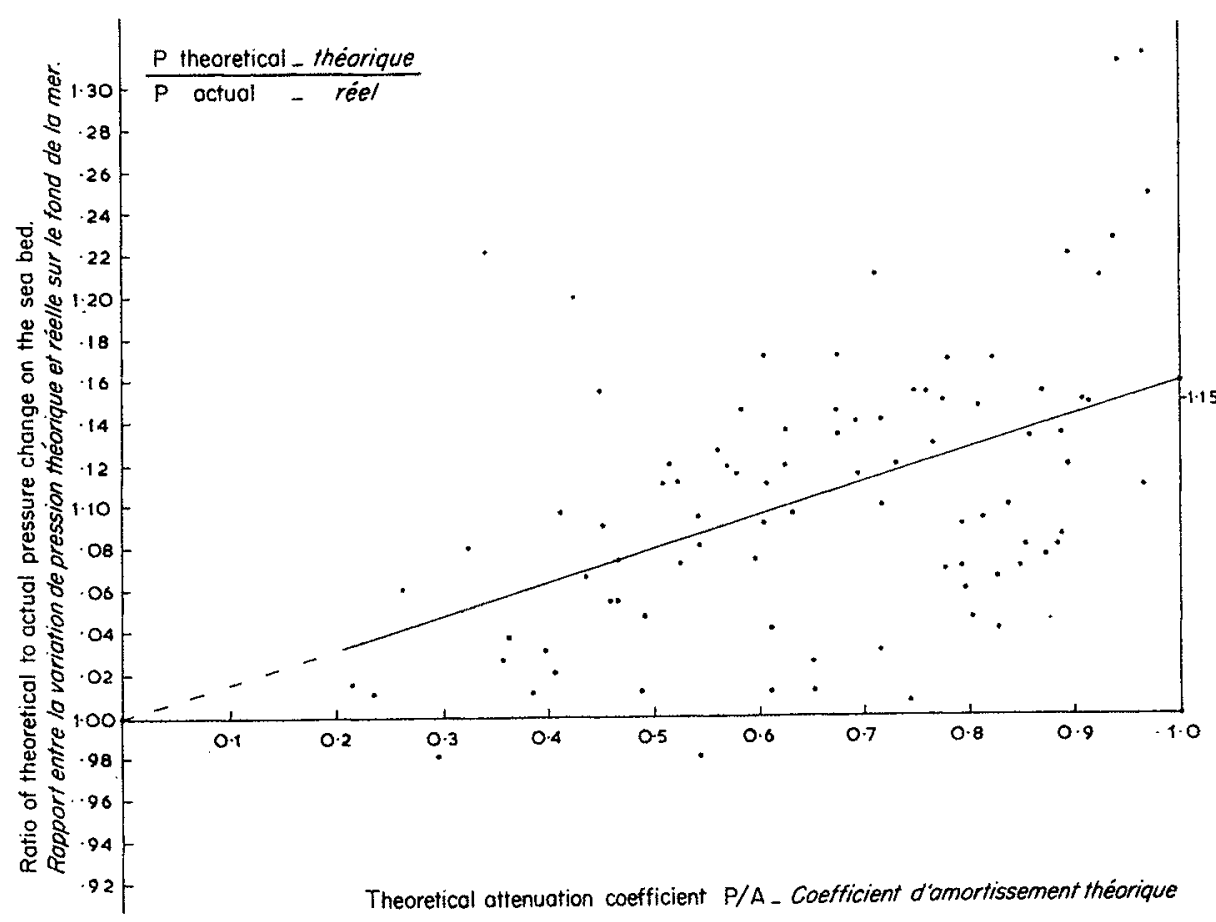

Flc. 3. -...-Variations du rapport entre écarts théoriques ot mesurés des pressions sur le fond, en fonction du coefficient d'amortissement théorique.

Graph of the ratios of theoretiral to actual pressurechange amplifudes on the sea bed plotted against the theoretical attennation fator.

plus faible dispersion, la droite fournie par la méthode des moindres carrés passé par le point :

$$
\frac{\mathrm{P} \text { théor. }}{\mathrm{P} \text { réelle }}=0,99
$$

Sur la figure 3 , nous avons légèrement corrigé cette droite pour la faire passer par le point 1,0 adjusted to pass through 1.00 with the slope unaltered. This amount of adjustment is not unreasonable in view of the large scatter, and it is well within the error range. If it is assumed that the relationship is linear, as in fig. 3 , a simple expression can be given for the calculation of the surface spectrum if the pressure spectrum at any given 
sans modifier sa pente, ce qui est bien légitime, car les valeurs étaient fortement dispersées et la correction appliquée bien en deçà de la marge d'erreurs. En admiettant une relation linéaire, comme sur la figure 3 , on arrive à une expression simple qui permet de calculer le spectre de surface quand on connaît le spectre des pressions au point considéré. On déduit du diagramme l'équation :

$$
\mathrm{P}=\left(\mathrm{A} \operatorname{sech} \frac{2 \pi d}{\lambda}\right) /\left(1+0,16 \operatorname{sech} \frac{2 \pi d}{\lambda}\right)
$$

ou :

$$
\mathrm{A}=\mathrm{P}\left(0,16+\cosh \frac{2 \pi d}{\lambda}\right)
$$

\section{Erreurs possibles}

\section{introduites par l'appareillage enregistreur}

On peut supposer que les erreurs maxima dues à l'appareillage enregistreur sont les suivantes : Enregistreur de surface.... +2,5\% - $4 \%$ Enregistreur de pression... $\doteq 4 \%$ Erreur totale maximum... $+6,5 \%-8 \%$

Pour estimer la limile probable des erreurs, on forme pour chacune des opérations la racine carrée de la somme des carrés des erreurs probables maximum; on arrive ainsi à une erreur possible comprise entre $+2,9 \%$ et $-3,9 \%$.

Des erreurs fortuites se glissent aussi dans l'analyse; elles sont dues aux variations de l'intensité lumineuse des lampes du système oplique de détection, causées par les fluctuations dans les canalisations et au caractère non linéaire du système optique; mais les erreurs se compensent entre elles dans la masse des obserrations.

\section{Commentaires}

Les recherches dont il vient d'ètre question ont montré que les houles en eau relativement profonde (par rapport à leur longueur d'onde) obéissent à la théorie hydrodynamique classique de l'amortissement en fonction de la profondeur, tandis que les houles en eau peu profonde peuvent engendrer sur le fond des variations de pression parfois plus faibles d'environ $20 \%$ que celles que prédit la théorie. C'est surprenan!, car on pourrait s'attendre à ce que les pressions dues aux houles les plus longues s'approchent du cas statique et concordent à peu près exactement avec la théorie. Il se peut aussi que, la plage se trouvant pour les houles les plus longues à une distance de l'ordre de la longueur d'onde, le mouvement de l'eau ait été suffisamment troublé pour provoquer cette réduction d'amplitude. Le fait d'avoir un fond mobile ne pourrait conduire qu'à de faibles erreurs dans ce domaine. point is known. The equation derived from this graph is:

$$
\mathrm{P}=\left(\mathrm{A} \operatorname{sech} \frac{2 \pi d}{\lambda}\right) /\left(1+0.16 \operatorname{sech} \frac{2 \pi d}{\lambda}\right)
$$

or:

$$
\mathrm{A}=\mathrm{P}\left(0.16+\cosh \frac{2 \pi d}{\lambda}\right)
$$

\section{Errors in the recording equipment}

It is estimated that the maximum possible errors in the recording equipment are as follows:

Surface recorder ........... +2.5\% - $4 \%$

Pressure recorder ........ $\pm 4 \%$

Total maximum error ........ +6.5\% - 8\%

An estimate of the probable limits of the errors is obtained by laking the square root of the sum of the square of the probable maximum errors in each operation; this gives the estimated error range as $+2.9 \%$ to $-3.9 \%$.

There are random errors in the analyses, due to variations in the lamp intensity of the optical pick-up system, caused by mains fluctuations and non-linearity of the optical system, but these should average out over the number of observations made.

\section{Discussion}

From these investigations it appears that waves which are in relatively deep water (compared with their wavelength) obey the classical hydrodynamical theory for attenuation with depth, whereas waves in shallow water may produce pressure changes on the sea bed almost $20 \%$ less than that suggested by the theory. This is surprising, as the pressures from the longer waves would be expected to tend towards the static case and agree almost exactly with theory. It may be that as the beach was only of the order of a wavelength away for the longer waves the water motion was modified sufficiently to cause this reduction in amplitude. Non-rigidity of the sea bed would produce only a small error in this direction.

The rather widespread distribution of the points on the final graph is produced partially by the 
La répartition assez dispersée que l'on note parmi les points du diagramme tinal est en partie due aux défauts inhérents à l'enregistrement; mais il est plus probable qu'elle est due à des variations fortuites auxquelles serait sujet l'appareil analyseur, comme nous le disions au paragraphe relatif aux erreurs.

Il ne faut pas croire que les conclusions auxquelles nous sommes arrivés soient applicables $\dot{a}$ toutes les houles enregistrées sur le fond; mais comme ces enregistrements sont souvent effectués près du littoral, la formule classique, convenablement modifiée à l'aide de valeurs empiriques recueillies (3), pourrait s'avérer utile pour l'interprétation des résultats.

\section{Remerciements}

L'auteur exprime sa gratitude an Direcleur du National Institute of Oceanography et à ses collègues pour l'aide et les conseils qu'ils lui ont accordés, ainsi qu'aux Directeurs et au personnel de l'Eastbourne Pier Company pour lui aroir facilité le travail. inherent noise in the records, but more probably by random variations in the analyser mentioned in the paragraph on errors.

These results cannot be expected to hold for all waves recorded on the sea bed, but as waves are often recorded fairly near to the shore the empirically modified classical expression (equation 3) should be of value in the interpretation of such records.

\section{Acknowledgements}

I should like to express my appreciation of the assistance and advice given by the Director and $m y$ colleagues of the National Institute of Oceanography, also to the Directors and staft of the Eastbourne Pier Company for their kindness in providing accommodation and facilities for the work.

\section{BIBLIOGRAPHIE - BIBLIOGRAPHY}

(1 a) R.G. Folson. "Subsurface pressures due to oscillatory waves ». Trans. Amer. geophys. Un. Yol. 28, $n^{\circ} 6$, December 1947 .

(1 b) K.F. Bownen. "Some observations of waves and other fluctuations in a tidal current $\gg$. Proc. Roy. Soc., A, Vol. 192, February 1948, 403-425.

(1 c) H.R. Serwell. "Investigation of bottom pressurc fluctuations and surface waves $\gg$. M.I.T. de Woods Hole Papers in Physical Oceanography and Meteorology. (Part I of « Results of research on surface waves of the western North Atlantic). Vol. 10, $n^{\circ} 4$, August $1948,1-56$.

(l $d$ ) R.G. Folsom. "The measurement of ocean wayes Trans. Amer. geophys. Lin. Vol. 30, 1949, 691-699.

(1 e) R.I.B. Cooper \& M.S. Longuet-Higins. « An experimental study of the pressure variations in standing water waves ». Proc. Roy. Soc., A, Vol. 20t, $1951,424-435$.

(1 f) J.R. Monison. «Analysis of subsurface pressure records in constant depths and on sloping beaches.
Univ. of California Institute of Engineering Research pubn., Séries 3, Issue 336, May 1952.

( 1 g) J.R. GenhaRd, K.H. Jehn \& I. Katz. «A comparison of step-, pressure-, and continuous wire-gage wave recordings in the Golden Gate channel». Trans. Amer. geophys. Ein., Vol. 36, April 195.), $235-250$.

(2) M.J. Treker \& H. Chansock. "A capacitance-wire recorder for small waves s. Proc. Fifth Conference on Coastal Engineering, Grenoble, September 195\%, $177-188$.

(3) O. Snstr. «Ripple tank studies of the motion of surface gravity-waves ». I'nib. of California Institule of Engineering Research pubn., Series 3, Issue 346 , February 1953.

(4) M.J. Traker. "The N.I.o. Wave Analyser». Pror. First Conference on Coastal Engineering Instruments, Berkeley, California, 31 October to 2 November 1955, 129-133. 